\title{
Epistemological Disjunctivism and the New Evil Demon
}

\author{
BJC Madison \\ (Forthcoming in Acta Analytica, 2013) \\ Draft Version - Do Not Cite Without Approval
}

\section{I) Introduction:}

The dispute between epistemic internalists and epistemic externalists is deep, seemingly intractable, and one with no simple resolution in sight. On the face of it, one cannot help but think that each side of the debate is on to something epistemically important: internalists with their focus on epistemic responsibility and rationality being a matter of the first person perspective; externalists with their emphasis on truth-conduciveness and aiming to achieve the right objective fit between our beliefs and the world they purport to represent.

On the other hand, both internalism and externalism seem problematic in ways that the other side of the divide promises to rectify: internalists face the difficult question of specifying what the relation is between justification and truth, whereas externalists have a straightforward answer to this issue, but at the cost of divorcing justification from epistemic rationality. Given that epistemic internalism and epistemic externalism are standardly understood as mutually exclusive and jointly exhaustive accounts of the fundamental nature of epistemic justification, however, it seems at best some serious concessions must be made in order to advance the debate.

But what if we could have the best of both worlds? Epistemological disjunctivism promises exactly that. In fact for this reason, Duncan Pritchard, a recent chief proponent of the view, has gone so far as to call epistemological 
disjunctivism the "holy grail" of epistemology (Pritchard, 2012, p. 1). One of its promised aims is to reconcile epistemic internalism and externalism, incorporating important insights from each, namely: an awareness condition on justification, as the internalist emphasizes, while at the same time holding on to a robust connection between justification and truth, as the externalist emphasizes.

This paper shall critically examine the bold claim made by epistemological disjunctivists that their view is able to peacefully reconcile epistemic internalism and epistemic externalism. I shall argue that, on the contrary, epistemological disjunctivism fails to do justice to the motivations for internalism, and that the account given of these motivating intuitions is at best incomplete. Unfortunately, therefore, at present the impasse between internalism and externalism remains.

\section{II) What is Epistemic Internalism?}

Epistemic internalists hold that all the relevant factors that determine justification must be "internal" (in a sense that needs to be specified). Traditional forms of epistemic internalism tend to stress the epistemological significance of consciousness. ${ }^{1}$ A traditional way in which the epistemically internal is understood maintains that it is a necessary condition of being justified in holding a particular belief that the subject is consciously aware of some reason to think that the belief is true (or that the subject could easily become aware of the reason, upon reflection).

\footnotetext{
${ }^{1}$ The other way that epistemic internalism has been understood is in terms of being internal to a subject's mental life; "Mentalism", as it is known, holds that a subject's justification supervenes on her (non-factive) mental states. See Feldman and Conee 2001 and 2008, as well as Wedgwood 2002, for expressions of this view. A referee for this journal pointed out that Wedgwood's Mentalism is cast in terms of (epistemic) rationality, rather than justification per se. Wedgwood 2002 is open to the possibility that there is a notion of epistemic justification distinct from rationality.
} 
However, it is not enough that subjects are merely aware of the existence of their grounds; they must appreciate the existence and relevance of the grounds to what is believed. Specifically, epistemic internalists ought to endorse:

AWARENESS: $\mathrm{S}$ is justified in believing that $p$ only if

(i) there is something, $\mathrm{X}$, that contributes to the justification of belief $\mathrm{B}$; and

(ii) for all $\mathrm{X}$ that contributes, $\mathrm{S}$ is aware (or potentially aware) that $X$ contributes to the justification of belief $B{ }^{2}$

In addition to demanding awareness as a necessary condition for justification, traditional internalists think of their position as the conjunction of AWARENESS and DEMON:

DEMON: factors external to the subject's awareness, such as the reliability of the mechanism that gave rise to the belief, are not necessary for the belief to be justified.

DEMON tends to be supported by appealing to intuitions that give rise to what has become known as the New Evil Demon problem (Lehrer and Cohen 1983; Cohen 1984). I shall say more about this problem below.

Epistemic internalism, therefore, will be understood as any view which endorses the Awareness Requirement, and that holds that factors external to such awareness play no justificatory role. That is to say, epistemic internalism is a thesis about epistemic justification that holds that all the factors upon which justification supervenes are "internal" to the subject, where the epistemically internal is captured

\footnotetext{
${ }^{2}$ This formulation is similar to Bergmann 2006, p. 9. However Bergmann's formulation has been amended to rule out considerations making a justificatory difference if the subjects fail to appreciate their existence or relevance to what is believed.
} 
by the conjunction of AWARENESS and DEMON. Externalism will be understood as the denial of internalism. ${ }^{34}$

As we shall see, epistemological disjunctivism is revisionary in accepting an awareness requirement while rejecting DEMON - notably, however, the epistemological disjunctivist claims to be able to do justice to all the considerations motivating the traditional internalist, while preserving advantages from externalism, and so argues that their view is to be preferred. I shall argue that the epistemological disjunctivist's treatment of the New Evil Demon case is inadequate, and so their defense of their position is incomplete at best.

\section{III) What is Epistemological Disjunctivism?}

At heart, epistemological disjunctivism is characterized by Duncan Pritchard as follows:

\section{Epistemological Disjunctivism: The Core Thesis}

In paradigmatic cases of perceptual knowledge an agent, $\mathrm{S}$, has perceptual knowledge that $\phi$ in virtue of being in possession of rational support, $R$, for her belief that $\phi$ which is both factive (i.e. $R$ 's obtaining entails $\phi$ ) and reflectively accessible to S. (Pritchard, 2012, p. 13)

If a state is factive, it entails that its content is true. For example, the states of seeing that $p$, hearing that $p$, or knowing that $p$, entail that $p$ is true. If $p$ were false, at

\footnotetext{
${ }^{3}$ For a recent critical survey of problems and prospects in the contemporary literature on the internalism / externalism distinction in epistemology, as well as for various ways of drawing the distinction, see Madison 2010.

${ }^{4}$ While traditional forms of epistemic internalism ought to embrace both AWARENESS and DEMON, some authors have accepted DEMON but not AWARENESS, for example Ralph Wedgwood 2002, and arguably Earl Conee and Richard Feldman 2001; 2004; 2008; whereas some have accepted AWARENESS but not DEMON, for example Duncan Pritchard 2008; 2012, and arguably John McDowell 1998a; 1998b; 1998c.
} 
best one could only seem to see that $p$, seem to hear that $p$, or seem to know that $p$ (i.e. maybe one would believe or otherwise take oneself to know that $p$-- but one would be mistaken).

What then is reflective accessibility? Surprisingly, Pritchard says very little in detail. Here is what he does say about reflective accessibility: "this usually means that the subject can come to know through reflection alone that she is in possession of this rational support." (Ibid.) Not much else is said about the nature of reflective accessibility, or what precisely motivates the reflective accessibility condition, other than the claim that "if this rational support were not so accessible - if, in particular, it was opaque to one that one's belief enjoyed this rational support - then it would be hard to see why it would count as rationally supporting your belief that p." (Prichard, 2012, p. 14) Pritchard directs the reader to Chisholm (1977) and Bonjour (1985) for the details of what the access requirement amounts to. According to Chisholm, what makes a reason reflectively accessible is that it can be known on the basis of introspection or reason alone.

To concretely illustrate how the view is meant to work, consider an example: suppose one sees that a ship is in harbour, and on that basis one believes that a ship is in harbour. According to the epistemological disjunctivist, one is thereby in a position to know that ship is in harbour. Distinctively, it is claimed that one's rational support, what makes one's belief epistemically rational or justified, is the truthentailing state of one's seeing that a ship is in harbour (which is a different state than merely seeming to see that a ship in harbour). In addition, the epistemological disjunctivist holds that this reason is reflectively accessible to one, in that it is claimed that one can know through introspection alone that one is seeing a ship in harbour, since this is a conscious perceptual experience that one is undergoing. 
If the key aspect of epistemological disjunctivism is its insistence on the reflective accessibility of truth-entailing reasons, that together with belief, are sufficient for knowledge (Pritchard, p. 14), what about the view is disjunctive? The disjunctive aspect of the position is that even if two subjects enjoy subjectively indistinguishable reasons for their beliefs, they need not be on rational par. For example, either $\mathrm{S}$ sees that $p$, and so $\mathrm{S}$ thereby is in a position to know that $p$, or else $\mathrm{S}$ merely seems to see that $p$ (perhaps he is hallucinating), and so he is not in a position to know that $p$. In a case of a non-veridical hallucination, obviously what is believed is false, so no party to the debate would maintain that the subject has knowledge.

So, according to Pritchard, what is distinctive about epistemological disjunctivism is the claim that subjects in 'good' (veridical) and 'bad' (hallucinatory / illusory) cases differ in their rational standings: in the bad case the subject is less rational, or perhaps less epistemically justified, in believing as they do ${ }^{5}$. Perhaps in the bad case the agent's belief enjoys some positive epistemic status, such as being held blamelessly, but according to the epistemological disjunctivist, the rational standing is inferior to what it would have been, had the agent's belief been enjoying subjectively indistinguishable factive support. ${ }^{6}$

\footnotetext{
${ }^{5}$ Indeed not only is the subject meant to be rationally worse off in the bad case than in the good case as a matter of degree, but according to the epistemological disjunctivist, "the two rational standings are radically different in kind." (Pritchard, 2012, p. 16)

${ }^{6} \mathrm{~A}$ referee for this journal questioned whether this characterization is really distinctive of epistemological disjunctivism. After all, many externalists will hold that there is a difference in rational standing between the good and bad cases. For example, Jonathan Sutton (2007) argues that one is justified in believing that $\mathrm{p}$ iff one knows that $\mathrm{p}$. Since one fails to know in the bad case, on his account, one thereby fails to believe with justification in the bad case. Nothing about Sutton's position seems distinctively disjunctive, however. So the question of how best to formulate epistemological disjunctivism is still an open question. For my present purposes, however, what remains key is Pritchard's Core Thesis and his claim that it can be reconciled with all the intuitive motivations for epistemic internalism, including the New Evil Demon problem.
} 
To illustrate this crucial point, return to our example above of seeing a ship. Compare two subjects: one sees that a ship is in harbour, and on that basis believes that a ship is in harbour. The second subject, let us suppose, is the victim of an evil demon. The demon feeds him a hallucinatory visual experience so that it seems to him that a ship is in harbour, although there is no ship present. Nevertheless, on the basis of seeming to see that a ship is in harbour, the subject believes that there is. Now obviously the second subject does not know that a ship is in harbour, if for no other reason than that belief is false. But according to the epistemological disjunctivist, the pair of subjects are not equally rational or justified in believing as they do; the first subject is rational and justified in believing as he does; the second is not (or, at the very least, the second subject is less rational, and less justified, than the first).

Pritchard's main dialectical strategy is not to directly motivate epistemological disjunctivism as such; rather, his aim is to present the position, and then defend it against a series of objections which many have thought are fatal to the view (see parts 1 and 2 of Pritchard 2012). His primary aim is thus to show that the position is a viable theoretical option which, if true, would have important epistemological implications, including a response to the skeptical paradox, as well as going some way to reconciling the debate between internalists and externalists (Pritchard, 2012, p. 18).

I shall now argue that epistemological disjunctivism fails to make good on its claim to bring a reconciliation between epistemic internalists and epistemic externalists. In order to see this, we need to need to examine the New Evil Demon problem and the epistemological disjunctivist's treatment of it. 


\section{IV) The New Evil Demon:}

Recall that according to traditional forms of internalism (i.e. both forms of access internalism as well as Mentalism), there is a condition that holds that factors external to the subject's awareness, such as the reliability of the mechanism that gave rise to the belief, are not necessary for the belief to be justified. I called this condition DEMON. Duncan Pritchard captures the idea as follows:

\section{The New Evil Genius Thesis}

S's internalist epistemic support for believing that $\phi$ is constituted solely by properties that $\mathrm{S}$ has in common with her recently envatted physical duplicate. (Pritchard, 2012, p.38)

DEMON tends to be supported by appealing to a variety of thought experiments that have given rise to what has become known as the New Evil Demon problem (Lehrer and Cohen 1983; Cohen 1984; for a critical survey of the problem and responses to it, see Littlejohn 2009a).

One form of the argument proceeds by comparing what constitutes justified belief for one who lives in the actual world with what constitutes justified belief for one's counterpart who lives in a demon world, like the one entertained in Descartes' First Meditation. By hypothesis, the demon world is one which is from our own perspective just like the actual world. What we experience and believe in the demon world is the same as in the actual world, except crucially, that the demon ensures that all of our empirical beliefs are false. ${ }^{7}$ Nevertheless, internalists point out the intuitive

\footnotetext{
${ }^{7}$ Some externalists about mental content, however, may deny that such a case is possible. That is, they may deny that there could be a world where a counterpart has all the same beliefs that we do, but that all of their empirical beliefs are false. Since many people hold that some form of content externalism is true, if it is incompatible with epistemic internalism, this would seriously threaten the position. For charges that content externalism and epistemic internalism are incompatible, see for example Pritchard
} 
plausibility of holding that the counterparts are equally justified in believing as they do: their beliefs are justified to the very same extent, sharing sameness of justificatory status.

In common with traditional forms of epistemic internalism, epistemological disjunctivism attempts to incorporate an awareness condition, as we have seen. Unlike traditional forms of internalism, however, epistemological disjunctivism rejects the New Evil Genius thesis: a subject and her recently envatted counterpart may have subjectively indistinguishable perceptual experiences, for example, but only in the veridical case is the subject justified. In so far as epistemological disjunctivism rejects the New Evil Genius thesis, it is revisionary. Given Pritchard's stated aim of incorporating insights from both internalists and externalists, some adequate account needs to be given of the intuitions that support the New Evil Demon case, since it is ultimately rejected. Pritchard himself notes the importance of being able to provide such an account:

Does this mean that epistemological disjunctivists are committed to rejecting the intuitions which drive the new evil genius out of hand? If so, then that would be a problem for epistemological disjunctivism, since the view could then be charged with being unable to accommodate the core guiding intuitions of epistemic internalism. (Pritchard, 2012, p.42)

Before examining the epistemological disjunctivist's proposed error theory, it is important to understand on what basis the traditional epistemic internalist holds the New Evil Genius thesis. Pritchard examines arguments that reason to the New Evil Genius thesis as a conclusion from various premises, such as Accessibilism

and Kallestrup 2004; Williamson 2007. For replies that the two views are compatible, see for example Gerken 2008; Madison 2009. 
(Pritchard, 2012, p. 39), as well as Mentalism (Ibid., p.40). Whether or not these arguments are sound, it is important to see that the epistemic internalist who endorses the New Evil Genius thesis need not attempt to derive the thesis in this way. Rather, the New Evil Genius thesis enjoys independent support.

The New Evil Genius thesis follows from our evaluative judgments about sameness of justification between counterparts. But is our claim about sameness of justification not derivative from something more basic? It is difficult to say. But what is important here is that our claim to sameness of justification is an evaluative thesis, not an explanatory thesis. ${ }^{8}$ It says only that epistemic counterparts internally alike are justificationally alike; not why or in virtue of what are they so justified. As Nico Silins has pointed out, this is a virtue of evaluative theses in general, since what supports them is pure intuitive plausibility, not motivations from theoretical judgments about the nature of justification (Silins, 2005, p. 386). As relatively pretheoretical judgments, they can be used as data in philosophical theory building. Such data should be used unless we have good reason to reject it. We can see from the above quote that Pritchard himself would agree with this basic methodology (Pritchard, 2012, p. 42).

With this basic point about methodology in place, the traditional internalist ought to argue as follows: the first step is to present New Evil Demon thought experiments. The second step is to register the evaluative judgment that there is sameness of justification between normal world subjects and their demon-world counterparts, as well as differences in justification between equally unreliable subjects in the demon world, i.e. between the 'good' and 'bad' reasoners in that world (cf.

\footnotetext{
${ }^{8}$ See Silins 2005 p. 385 for discussion of evaluative v. explanatory theses in epistemology.
} 
Cohen 1984). These are purely evaluative judgments about the presence of justification in various hypothetical circumstances, not a conclusion reasoned to from various premises. The third step is then to draw lessons from these cases and our judgments about them. So from the judgment that justification could still be present in a demon world, epistemic internalists can then argue by inference to the best explanation that justification therefore must be an internal matter in various senses, including that captured by the New Evil Genius view (that is, that S's internalist epistemic support for believing that $\phi$ is constituted solely by properties that $\mathrm{S}$ has in common with her recently envatted physical duplicate). This must be so, an internalist should argue, in order to account for our evaluative judgments about the presence of justification in the demon world.

Given this traditional internalist dialectic, we can see that in fact the order of explanation between Accessibilism, Mentalism, and the New Evil Genius view should be taken as the exact opposite to what Pritchard proposes. That is to say, the traditional internalist ought to argue as follows: given the truth the of the New Evil Genius thesis, not only is conscious awareness of one's grounds necessary for a belief to be justified (as shown by clairvoyance-style cases), but factors external to such awareness are not necessary for justification either. In addition, given the truth of the New Evil Genius thesis, Mentalism is true: justifiers must be mental, since plausibly what could be in common between the first-person perspectives of those in the normal world and their counterparts in the demon world is something mental (such as an appearance- state or a seeming), rather than external objects and their properties. In short, the traditional internalist ought to argue from the New Evil Genius thesis to Accessibilism and Mentalism, not the other way around. 
Having made clear how best to motivate the New Evil Genius thesis, we can now examine the epistemological disjunctivist's rejection of it, as well as how successfully they account for the intuitions that support it. On this score, Pritchard writes,

As we have seen, epistemological disjunctivists are committed to rejecting this [New Evil Genius] thesis, since on this view a subject's internalist epistemic support for her beliefs can be very different depending on whether she is envatted. But that doesn't mean that epistemological disjunctivists are obliged to argue that there isn't an internalist epistemic standing which is common to both the subject and her envatted duplicate. In particular, it is widely noted about the subjects in the new evil genius example that one epistemic standing that they share is that they are equally blameless in believing as they do. (Original emphasis) (Pritchard, 2012, p. 42)

It is true that a subject and her recently envatted counterpart are equally blameless in believing as they do. But can that really be a sufficient explanation as to why we judge that they are equally justified? Why are the subjects equally blameless in believing as they do? One straightforward explanation of why they are equally blameless is because they are equally justified in their beliefs. After all, it is not the case that the subjects merely fail to violate any epistemic duties or obligations; rather, in addition, it seems that in a perfectly reasonable sense, they are believing as they ought to, given their grounds. If it seems to one's envatted counterpart that there is a tree before him, for example, then in the absence of some undercutting or rebutting reason to think that he is mistaken, the subject ought to believe that there is a tree before him. On the other hand, the subject would be quite unreasonable to suspend judgment on the issue of there being a tree before him, let alone disbelieve it, given what he seems to see. If such a subject is reasonable, rational, and believing as he ought to, this seems tantamount to believing with justification. 
But suppose that this is incorrect, and the subject in the demon world is not justified, or at least is less justified in believing what his normal world counterpart believes. Is it plausible to suggest that mere blamelessness is what the internalist confuses for justification in the demon world, as Pritchard suggests? By comparing several subjects, we can see that this explanation is not compelling ${ }^{9}$.

Suppose Al believes that a ship is in harbour because he seems to see one; $\mathrm{Al}^{*}$, his recently envatted counterpart, also believes that a ship is in harbour because he seems to see one, although he is hallucinating. Compare these two subjects with Bert who also believes that a ship is in harbour, but he believes this as the result of brainwashing. Lastly, compare these subjects with Carl who also believes that a ship is in harbour, but he believes this as the result of an as yet unnoticed cognitive malfunction: due to a recent brain injury, whenever he seems to smell freshly cut grass, he believes that there is a ship in harbour.

In the four cases above, the subjects all believe the same proposition, namely, that there is a ship in harbour. Further, all are blameless in believing as they do: the first two believe what their evidence supports; Bert, in turn, cannot be faulted for being the victim of brainwashing, nor can Carl be reproached for suffering an accident that results in non-standard belief-forming processes. While all are blameless in believing as they do, surely $\mathrm{Al}$ and $\mathrm{Al}$ * have better rational support for their beliefs than Bert and Carl do: they hold their belief on the basis of evidence which they take to support the truth of what is believed, whereas Bert and Carl do not.

Mere blamelessness is insufficient for the positive epistemic status of the beliefs in cases of subjects and their evil genius-deceived counterparts. It is therefore

\footnotetext{
${ }^{9}$ For a similar point, see Smithies 2013.
} 
implausible to suggest that the traditional internalist's judgments of sameness of justification in these cases could arise merely by confusing these two notions ${ }^{10}$. The epistemological disjunctivist's account of the intuitions underlying the New Evil Genius thought experiment is at best incomplete. As presented, therefore, it is unable to accommodate the core guiding intuitions of epistemic internalism and, given the stated aim of not being revisionary on this score, the view is at a dialectical disadvantage over the traditional forms of epistemic internalism the position is meant to replace.

\section{V) Conclusion:}

Epistemological disjunctivism has been called the Holy Grail of epistemology.

One of its promised aims is to reconcile epistemic internalism and externalism, incorporating insights from each. The traditional form of internalism that epistemological disjunctivism is meant to replace is characterized by an awareness

\footnotetext{
${ }^{10}$ Some have argued that what the internalist confuses is a person's being justified, v.s. their belief being justified. That is, a distinction is drawn between personal and doxastic justification. On this account, while the subjects may be justified in the New Evil Demon case, their beliefs are not. Advocates of this approach include Bach 1985, Engel 1992, Littlejohn 2009b. The plausibility of such a response will turn on the coherence of a subject being justified in believing that $p$ while his belief that $\mathrm{p}$ is itself unjustified. According to Kvanvig and Menzel 1990, for example, a person's being justified in believing that $\mathrm{p}$ entails that his belief that $\mathrm{p}$ is justified - one cannot have the former without the latter.
}

Another suggestion has been that what the internalist confuses for justification in the demon world is not mere blamelessness, but rather, is excusability, where excusability requires that the subject did what was reasonably expected to meet their obligations. Littlejohn $2009 \mathrm{~b}$, section III.4 provides an in-depth examination of ways in which a subject's beliefs and actions may be blameless, namely by being justified, by being exempt from responsibility, or by being excusable. According to this proposal, the subjects in the demon world are to be excused for their epistemic wrongdoing given their subjective perspective on the situation, even though the beliefs they hold are not justified.

Both of these are interesting proposals that deserve further attention. To be sure, however, neither of these proposals are offered by Pritchard in his defense of epistemological disjunctivism. It remains the case that the explanation given of the intuitions underlying the New Evil Demon problem is inadequate to the task at hand. 
condition on justification, as well as the acceptance of DEMON, which is taken to be a consequence of the New Evil Genius thesis.

As we have seen, however, epistemological disjunctivism has so far been unable to make good on at least one of its bold central claims: epistemological disjunctivism denies the New Evil Genius thesis, but fails to provide a convincing account of the intuitions that motivate the view - appealing to 'blamelessness' is insufficient to account for the judgment that things are going well in the demon world, insofar as the subject is believing rationally, reasonably, and as he ought, given how things seem to him. For all I have argued, epistemological disjunctivism may turn out to be an interesting and important epistemological view in its own right; however, it will be a form of epistemic externalism, not the promised happy rapprochement between internalism and externalism. Therefore, the Holy Grail of epistemology, if it exists, has yet to be found.

\section{Acknowledgements:}

Thanks to Tony Booth, Craig French, Stephen Hetherington, Rhiannon James, Guy Longworth, Vickie Madison, Declan Smithies, and an anonymous referee for Acta Analytica for helpful comments on earlier drafts of this paper. 


\section{References:}

Bach, Kent. (1985). A Rationale for Reliabilism. The Monist, 68, 246-63.

Bergmann, Michael. (2006). Justification Without Awareness. Oxford: Clarendon Press.

Bonjour, Laurence. (1985). The Structure of Empirical Knowledge. Cambridge, Mass.: Harvard University Press.

Chisholm, Roderick. (1977). Theory of Knowledge. $2^{\text {nd }}$ ed. Englewood, N.J.: Prentice Hall.

Cohen, Stewart. (1984). Justification and Truth. Philosophical Studies, 46, 279-295.

Conee, Earl \& Feldman, Richard. (2008). Evidence. In Quentin Smith (Ed.), Epistemology: New Essays, (pp. 84-104). Oxford: Oxford University Press.

Engel, Mylan. (1992). Personal and Doxastic Justification. Philosophical Studies, 67, 133-51.

Feldman, Richard \& Conee, Earl. (2001). Internalism Defended. In Hilary Kornblith (Ed.), Epistemology: Internalism and Externalism (pp. 231-260). Oxford: Blackwell Publishing.

Feldman, Richard \& Conee, Earl. (2004). Evidentialism. Oxford: Clarendon Press.

Gerken, Mikkel. (2008). Is Internalism About Knowledge Consistent With Content Externalism?. Philosophia, 36, 87-96.

Kvanvig, Jonthan \& Menzel, Christopher. (1990). The Basic Notion of Justification. Philosophical Studies, 59, 235-61.

Lehrer, Keith \& Cohen, Stewart. (1983). Justification, Truth, and Coherence. Synthese, 55, 191-207.

Littlejohn, Clayton (2009a) The New Evil Demon Problem. In: The Internet Encyclopedia of Philosophy. <

Littlejohn, Clayton. (2009b). The Externalist's Demon. Canadian Journal of Philosophy, 39, 399-434.

Madison, BJC. (2009). On the Compatibility of Epistemic Internalism and Content Externalism. Acta Analytica, 24, 173-183.

Madison, BJC. (2010). Epistemic Internalism. Philosophy Compass, 5(10), 840853.

McDowell, John. (1998a). Criteria, Defeasibility, and Knowledge. In John McDowell, Meaning, Knowledge, and Reality (pp. 369-394). Cambridge, Mass: Harvard University Press. 
McDowell, John. (1998b). Knowledge by Hearsay. In John McDowell, Meaning, Knowledge, and Reality (pp. 414-444). Cambridge, Mass: Harvard University Press.

McDowell, John. (1998c). Knowledge and the Internal. In John McDowell, Meaning, Knowledge, and Reality (pp. 395-413). Cambridge, Mass: Harvard University Press.

Pritchard, Duncan. (2008). McDowellian Neo-Mooreanism. In Adrian Haddock \& Fiona Macpherson (Eds.), Disjunctivism: Perception, Action, Knowledge (pp. 283310). Oxford: Oxford University Press.

Pritchard, Duncan. (2012). Epistemological Disjunctivism. Oxford: Oxford University Press.

Pritchard, Duncan \& Kallestrup, Jesper. (2004). An Argument for the Incompatibility of Content Externalism and Epistemic Internalism. Philosophia, 31, 345-354.

Silins, Nicholas. (2005). Deception and Evidence. Philosophical Perspectives, 19, 375-404.

Smithies, Declan (2013) Review of Duncan Pritchard, Epistemological

Disjunctivism. In Notre Dame Philosophical Reviews.

$<\underline{\text { http://ndpr.nd.edu/news/36590-epistemological-disjunctivism/>> }}$.

Sutton, Jonathan. (2007). Without Justification. Cambridge, Mass.: The MIT Press.

Wedgwood, Ralph. (2002). Internalism Explained. Philosophy and

Phenomenological Research, 65, 349-369.

Williamson, Timothy. (2007). On Being Justified in One's Head. In Timmons, Greco, Mele (Eds.), Rationality and the Good (pp. 106-122). Oxford: Oxford University Press. 